\title{
Aplikasi Augmented Reality Informasi Corak Endek Bali pada Platform Android
}

\author{
Kadek Dede Hendra Kusuma, I Ketut Adi Purnawan, Ni Kadek Dwi Rusjayanthi \\ Program Studi Teknologi Informasi Universitas Udayana \\ Bukit Jimbaran, Bali, Indonesia Telp. (0361) 701806 \\ e-mail : mail.dendrakusuma@gmail.com, dosenadi@yahoo.com, dwi.rusjayanthi@unud.ac.id
}

\begin{abstract}
Abstrak
Bali memiliki berbagai jenis kain dan salah satunya adalah Kain Endek Bali. Kain Endek Bali adalah kain tenun ikat yang cara pembuatannya dengan memberikan corak pada benang sebelum ditenun. Aplikasi Informasi Corak Endek Bali dikembangkan untuk mempermudah akses masyarakat tentang informasi corak Kain Endek Bali sehingga mendukung pelestarian dan eksistensi Kain Endek Bali seiring perkembangan zaman. Aplikasi Informasi Corak Endek Bali menerapkan teknologi Augmented Reality yang menggunakan library Augmented Reality Vuforia dengan Cloud Database Vuforia pada Platform Android. Aplikasi Augmented Reality Corak Endek Bali memiliki output video narasi online dengan running text tentang Informasi Corak Kain Endek Bali sesuai marker Corak Kain Endek Bali yang terdeteksi setelah proses scanning. Responden setuju aplikasi Augmented Reality Corak Endek Bali tergolong menarik dengan persentase sebesar $70 \%$ dan tergolong bermanfaat dengan persentase sebesar $90 \%$ berdasarkan hasil kuesioner yang diperoleh.
\end{abstract}

Kata kunci: Corak Endek Bali, Video, Informasi, Augmented Reality, Vuforia

\begin{abstract}
Bali has many kinds of local fabric, one of them is endek. Endek is an ikat weaving fabric, made by coloring the strings before getting weaved. Endek Bali Complexions Information System is developed in purpose to ease people in accessing information about endek complexions in Bali, so it can support the preservation and existance of endek. This application is applying augmented reality technology, using Vuforia Augmented Reality and Vuforia Cloud Database in an Android Platform. Endek Bali Complexions Information System will show online video naration with running text about endek complexions information right after the scanning process detected the endek complexions marker. $70 \%$ respondents agreed that Endek Bali Complexions Information System is interesting, and about 90\% respondents believed that this application is useful. Endek Bali Complexions Information System is developed in purpose to ease people in accessing information about endek complexions in Bali, so it can support the preservation and existance of endek.
\end{abstract}

Keywords: Endek Bali Complexions, Video, Information, Augmented Reality, Vuforia

\section{Pendahuluan}

Bali merupakan salah satu tempat yang memiliki kebudayaan dan wisata alam yang sangat terkenal di Negara Indonesia dan menjadi daya tarik pariwisata. Bali memiliki berbagai jenis kain dan salah satunya adalah kain endek. Kain endek adalah kain tenun ikat yang cara pembuatannya dengan memberikan corak pada benang pakan sebelum ditenun. Proses pemberian corak Kain Endek Bali dilakukan dengan cara mengikat bagian-bagian tertentu dari benang pakan sebelum dicelup sehingga terbentuk suatu corak [1]. Kain Endek Bali cukup dikenal wisatawan karena menjadi salah satu alternatif pilihan oleh-oleh kerajinan tangan selain itu kain Endek Bali juga sering digunakan oleh masyarakat Bali khususnya umat hindu dalam acara persembahyangan.

Kain Endek Bali memiliki bermacam-macam corak diantaranya corak alam seperti corak bunga dan binatang, corak patra bali, corak modifikasi dan lainnya. Kain Endek Bali juga dapat dikatakan warisan seni budaya Bali [1]. Ide pengembangan aplikasi Augmented Reality Informasi Corak Kain Endek Bali didasari pentingnya Kain Endek Bali sebagai salah satu warisan budaya, yang bertujuan mempermudah akses informasi mengenai corak kain endek 
Bali. Aplikasi Augmented Reality Informasi Corak Kain Endek Bali diharapkan mendukung dalam pelestarian dan menjaga eksistensi informasi corak Kain Endek Bali. Aplikasi Augmented Reality Informasi Corak Kain Endek Bali menerapkan teknologi Augmented Reality yang dapat menyajikan informasi menjadi lebih variatif dan menarik.

Augmented Reality (AR) adalah teknologi yang digunakan untuk mengkombinasikan antara dunia maya (virtual) dan dunia nyata (real) yang dibuat oleh komputer. Objek virtual yang dimaksud dapat berupa teks, animasi, model 3D atau video yang digabungkan dengan lingkungan sebenarnya sehingga pengguna merasakan objek virtual berada dilingkungannya. Augmented Reality adalah cara baru dan menyenangkan dimana manusia berinteraksi dengan komputer karena dapat membawa objek virtual ke lingkungan pengguna, memberikan pengalaman visualisasi yang alami dan menyenangkan [2].

Aplikasi Augmented Reality Endek Bali menerapkan metode marker atau penanda berupa gambar potongan Corak Kain Endek Bali. Aplikasi Augmented Reality Endek Bali dirancang menggunakan cloud database marker vuforia pada perangkat smartphone android dan web hosting untuk menyimpan data output aplikasi. Aplikasi Augmented Reality Endek Bali dirancang memiliki output berupa video narasi informasi corak kain endek Bali dan diperjelas kembali dengan running text tentang informasi corak kain endek Bali.

Penelitian lain tentang informasi kain yang dibuat dalam bentuk aplikasi augmented reality pada smartphone diantaranya penelitian Mario Fernando Rentor tentang aplikasi augmented reality pengenalan motif batik pada smartphone android menggunakan device database marker. Output dari aplikasi pengenalan motif batik ini adalah informasi berupa teks dari motif kain batik. Pengenalan motif kain batik Yogyakarta lebih mudah untuk dipahami dan diterima oleh berbagai kalangan masyarakat dengan aplikasi augmented reality pengenalan motif batik pada smartphone android [2].

Keberhasilan pemanfaatan Augmented Reality untuk mempermudah pengenalan motif batik mendasari pemanfaatan Augmented Reality pada penelitian ini. Aplikasi Augmented Reality Endek Bali pada Platform Android dikembangkan menggunakan Unity 3D. Aplikasi Augmented Reality Endek Bali dirancang dengan 2 aktor yaitu pengguna dan admin. Pengguna dapat mengarahkan smartphone pada marker Corak Kain Endek Bali untuk menampilkan video informasi tentang Corak Kain Endek Bali. Admin memiliki peranan dalam melakukan insert, update, dan delete data link video konten informasi dari Aplikasi Augmented Reality Endek Bali. Aplikasi Augmented Reality Endek Bali diharapkan mampu mempermudah akses informasi Corak Kain Endek Bali, memberikan informasi tentang Corak Kain Endek Bali yang lebih menarik sekaligus mendukung pelestarian Kain Endek Bali kepada masyarakat luas karena Kain Endek Bali merupakan salah satu warisan seni masyarakat Bali.

\section{Metodologi Penelitian}

Aplikasi Augmented Reality Informasi Corak Kain Endek Bali adalah sebuah aplikasi yang diimplementasikan pada Platform Android untuk menampilkan informasi tentang Corak Kain Endek Bali dengan lebih menarik sekaligus mendukung pelestarian Corak Kain Endek Bali. Metodologi penelitian meliputi alur penelitian pembuatan Aplikasi Augmented Reality Endek Bali, Data Corak Kain Endek Bali dan gambaran umum Aplikasi Augmented Reality Endek Bali.

\subsection{Alur Penelitian Pengembangan Aplikasi Augmented Reality Endek Bali}

Alur penelitian dari Aplikasi Augmented Reality Endek Bali yang dikembangkan ditunjukkan pada gambar 1 . 


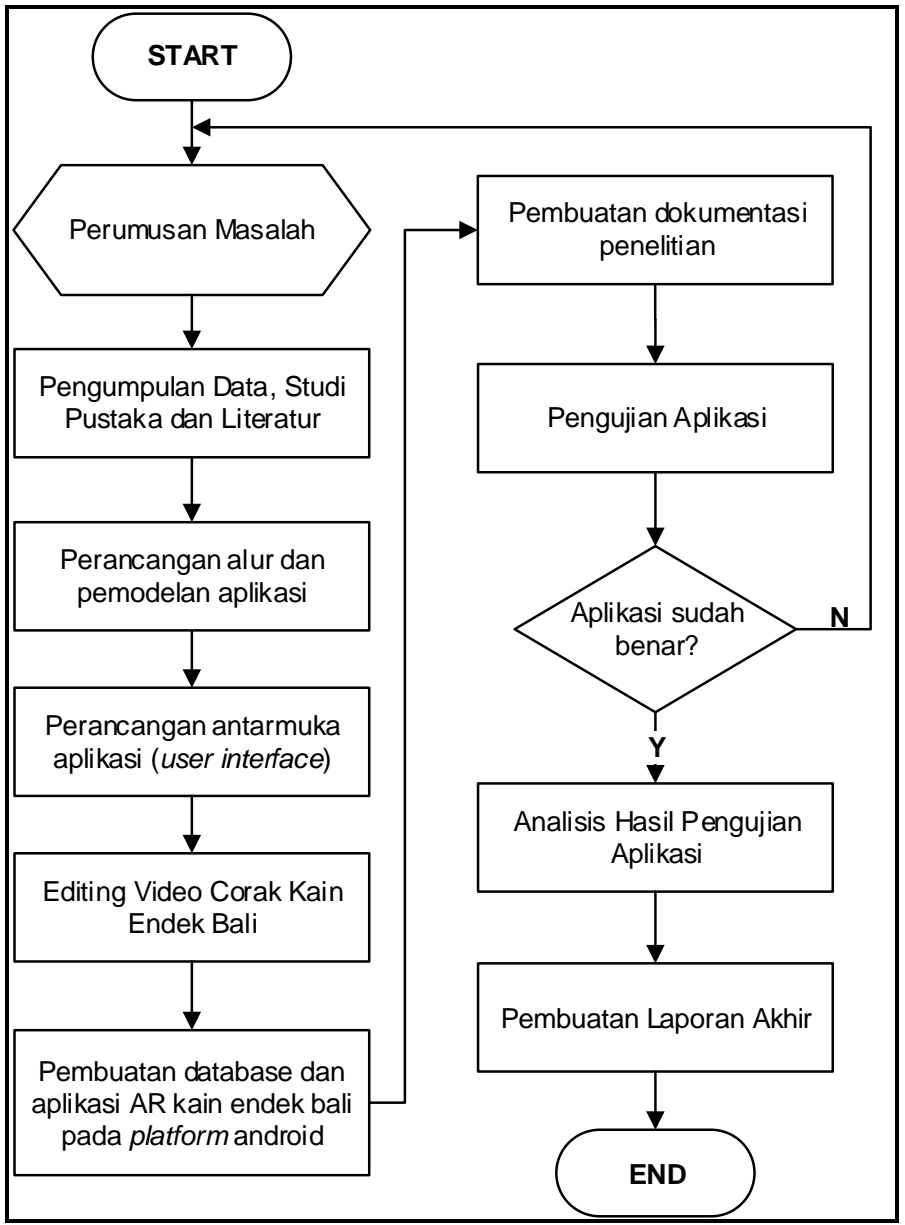

Gambar 1. Alur Penelitian Pengembangan Aplikasi Augmented Reality Endek Bali

Alur penelitian pengembangan Aplikasi Augmented Reality Endek Bali dimulai dari perumusan masalah Aplikasi Augmented Reality Endek Bali untuk mengetahui masalah dan tujuan pengembangan Aplikasi Augmented Reality Endek Bali. Selanjutnya, pengumpulan data dan studi pustaka serta perancangan alur dan pemodelan Aplikasi Augmented Reality Endek Bali untuk mendapatkan gambaran umum Aplikasi Augmented Reality Endek Bali. Perancangan antarmuka (user interface) Aplikasi Augmented Reality Endek Bali dilakukan untuk mendapatkan user interface Aplikasi Augmented Reality Endek Bali. Proses editing video Informasi Corak Kain Endek Bali adalah proses setelah perancangan user interface Aplikasi Augmented Reality Endek Bali. Proses editing video yang dilakukan adalah menambahkan narasi dan deskripsi teks Informasi Corak Kain Endek Bali dalam video Kain Endek Bali. Video Kain Endek Bali digunakan sebagai output Aplikasi Augmented Reality Endek Bali. Tahap selanjutnya adalah pembuatan cloud database sebagai penyimpanan data marker Corak Kain Endek Bali serta pembuatan Aplikasi Augmented Reality Endek Bali pada Platform Android, Pembuatan dokumentasi pengembangan Aplikasi Augmented Reality Endek Bali dilakukan sebagai bahan untuk pembuatan sebuah laporan. Pengujian Aplikasi Augmented Reality Endek Bali dilakukan untuk mendapatkan bahan analisis hasil pengujian Aplikasi Augmented Reality Endek Bali. Hasil analisis pengujian Aplikasi Augmented Reality Endek Bali digunakan untuk pengambilan kesimpulan dari pengembangan Aplikasi Augmented Reality Endek Bali. Tahapan terakhir adalah publikasi keseluruhan hasil dokumentasi, hasil pengujian, hasil analisis, dan kesimpulan Aplikasi Augmented Reality Endek Bali dalam sebuah laporan.

\subsection{Data Corak Kain Endek Bali}

Kain Endek Bali memiliki berbagai macam corak yang ada di masyarakat. Tabel 1 menunjukkan beberapa data corak dan deskripsi dari beberapa kain endek Bali yang dijadikan acuan pada cloud database Aplikasi Augmented Reality Endek Bali. 
Tabel 1. Corak Kain Endek Bali

\begin{tabular}{|c|c|c|}
\hline No. & $\begin{array}{c}\text { Nama Corak Kain } \\
\text { Endek Bali }\end{array}$ & Deskripsi \\
\hline 1. & Corak Uang Kepeng & $\begin{array}{l}\text { Corak Uang Kepeng adalah corak kuno dan klasik yang } \\
\text { dibuat pengrajin kain endek dengan memadukan } 3 \text { warna } \\
\text { kain sekaligus yaitu warna kain merah bata muda, ungu } \\
\text { muda, dan kuning muda. }\end{array}$ \\
\hline 2. & Cora & $\begin{array}{l}\text { Corak Rangrang adalah corak yang biasa digunakan pada } \\
\text { kain rangrang yang memiliki nilai kesakralan yang tinggi. Ciri } \\
\text { kain endek bercorak Rangrang adalah memiliki warna } \\
\text { tradisional seperti biru dan cokelat muda yang berbentuk } \\
\text { wajik. Kain endek bercorak Rangrang digunakan sebagai } \\
\text { pelengkap sarana upacara keagamaan dan sebagai pakaian } \\
\text { adat. }\end{array}$ \\
\hline 3. & 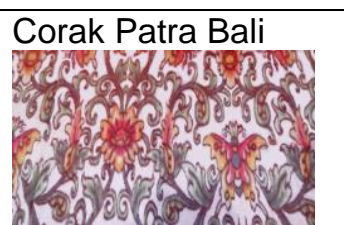 & $\begin{array}{l}\text { Corak Patra Bali adalah corak hasil modifikasi pengrajin kain } \\
\text { endek dengan model ukiran jenis tanaman rambat berbunga. } \\
\text { Teknik pewarnaan Corak Patra Bali dilakukan dengan teknik } \\
\text { air brush. }\end{array}$ \\
\hline 4. & Corak Geringsing & $\begin{array}{l}\text { Corak Geringsing yaitu corak kain asli dari Desa Tenganan, } \\
\text { Karangasem, Bali yang pada dasarnya hanya memakai } 3 \\
\text { warna dalam } 1 \text { kain yang disebut Tridatu terdiri dari warna } \\
\text { merah, kuning dan hitam. Kain Corak Geringsing biasanya } \\
\text { digunakan untuk sarana upacara. }\end{array}$ \\
\hline 5. & $\begin{array}{l}\text { Corak Cepuk } \\
\text { and }\end{array}$ & $\begin{array}{l}\text { Corak Cepuk adalah corak kain asli dari Desa Tanglad, Nusa } \\
\text { Penida, Bali yang berwarna merah khas disertai corak } \\
\text { warna-warni. Kain Corak Cepuk biasanya digunakan untuk } \\
\text { sarana upacara seperti penutup peti jenazah. }\end{array}$ \\
\hline 6. & $\begin{array}{l}\text { Corak Wajik Songket } \\
\text { Dasar Warna Biru }\end{array}$ & $\begin{array}{l}\text { Corak Wajik Songket Dasar Warna Biru adalah corak hasil } \\
\text { modifikasi pengrajin kain endek berbentuk wajik seperti corak } \\
\text { pada kain songket dengan dasar kain endek berwarna biru. }\end{array}$ \\
\hline 7. & & $\begin{array}{l}\text { Corak Jumputan adalah corak hasil modifikasi pengrajin kain } \\
\text { endek dengan teknik pewarnaan kain endek menggunakan } \\
\text { cara mengisi, melipat atau mengikat kain dengan cara } \\
\text { tertentu. Teknik pewarnaan tersebut membuat kain endek } \\
\text { memiliki suatu corak yang khas. }\end{array}$ \\
\hline 8. & $\begin{array}{l}\text { Corak Tumpal Dasar } \\
\text { Biru }\end{array}$ & $\begin{array}{l}\text { Corak Tumpal adalah corak berbentuk segitiga sama kaki. } \\
\text { Corak Tumpal Dasar Biru adalah corak hasil modifikasi } \\
\text { pengrajin kain endek berbentuk tumpal pada dasar kain } \\
\text { endek berwarna biru. }\end{array}$ \\
\hline
\end{tabular}




\begin{tabular}{|l|l|l|}
\hline 9. & $\begin{array}{l}\text { Corak Tumpal Dasar } \\
\text { Merah } \\
\text { Corak Tumpal adalah corak berbentuk segitiga sama kaki. }\end{array}$ & $\begin{array}{l}\text { Corak } \\
\text { Corak Tumpal Dasar Merah adalah corak hasil modifikasi } \\
\text { pengrajin kain endek berbentuk tumpal pada dasar kain } \\
\text { endek berwarna merah. }\end{array}$ \\
\hline 10. & $\begin{array}{l}\text { Corak Capung dan } \\
\text { Sekar }\end{array}$ & $\begin{array}{l}\text { Corak Capung dan Sekar adalah corak serangga dan bunga } \\
\text { hasil modifikasi pengrajin kain endek. }\end{array}$ \\
& \multicolumn{1}{|c|}{$\mid$}
\end{tabular}

Beberapa nama corak kain endek Bali dalam Tabel 1 seperti corak uang kepeng, corak rangrang, corak patra bali, corak geringsing, corak cepuk, corak wajik songket dasar warna biru, corak jumputan, corak tumpal dasar biru, corak tumpal dasar merah, serta corak capung dan sekar digunakan dalam pembuatan database marker Aplikasi Augmented Reality Endek Bali.

\subsection{Gambaran Umum Aplikasi Augmented Reality Endek Bali}

Gambaran umum Aplikasi Augmented Reality Endek Bali pada Platform Android yang ditunjukkan pada Gambar 2.

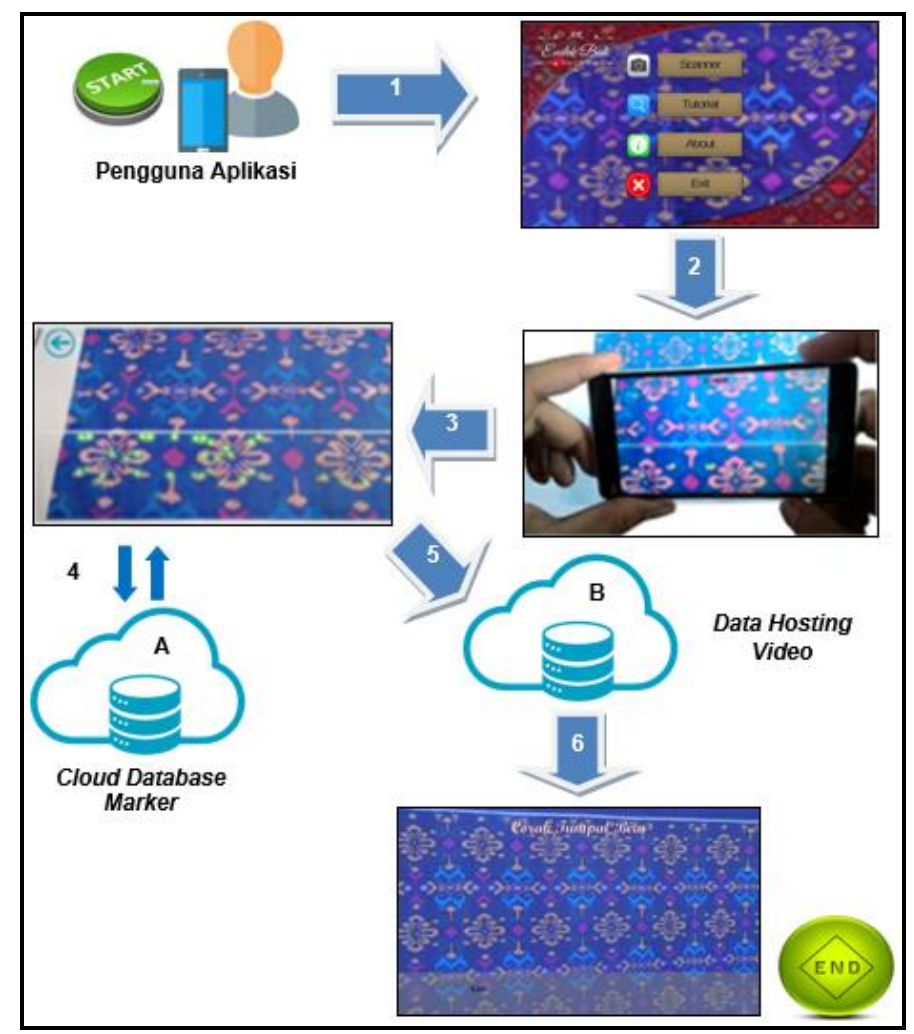

Gambar 2. Gambaran Umum Aplikasi Augmented Reality Endek Bali pada Platform Android

Aplikasi melakukan proses scanning pada sebuah marker Corak Kain Endek Bali, kemudian secara online marker Corak Kain Endek Bali dicocokan dengan cloud database marker. Aplikasi Augmented Reality Endek Bali menampilkan output video informasi dengan suara narasi dan running text dari Corak Kain Endek Bali sesuai dengan marker yang berhasil terdeteksi. Marker terdeteksi ketika proses scanning antara marker dengan target corak kain endek Bali pada cloud database vuforia cocok. 


\section{Kajian Pustaka}

Kajian pustaka merupakan pemaparan teori-teori penunjang yang menjadi dasar dalam perancangan Aplikasi Augmented Reality Informasi Corak Kain Endek Bali pada Platform Android.

\subsection{State of the Art}

Penelitian tentang teknologi Augmented Reality mengenai informasi kain pada smartphone sebelumnya telah dilakukan oleh peneliti bernama Mario Fernando Rentor yang berjudul "Rancang Bangun Perangkat Lunak Pengenalan Motif Batik Berbasis Augmented Reality" yang merupakan aplikasi augmented reality pengenalan motif batik pada smartphone android menggunakan device database [2]. Output dari aplikasi AR Batik adalah informasi berupa teks dari motif kain batik. Motif kain batik yang digunakan, dibatasi dan batik yang dipilih adalah batik motif Yogyakarta. Database yang digunakan pada aplikasi AR Batik adalah device database. Pengenalan motif kain batik Yogyakarta lebih mudah untuk dipahami dan diterima oleh berbagai kalangan masyarakat melalui aplikasi AR Batik. Ide pengembangan Aplikasi Augmented Reality Informasi Corak Kain Endek Bali pada Platform Android dalam penelitian ini, diperoleh dari Perangkat Lunak Pengenalan Motif Batik Berbasis Augmented Reality oleh Mario Fernando Rentor. Aplikasi Augmented Reality Informasi Corak Kain Endek Bali pada Platform Android menerapkan metode marker atau penanda berupa gambar Corak Kain Endek Bali. Aplikasi Augmented Reality Endek Bali dirancang dengan cloud database marker vuforia dan data output aplikasi disimpan pada sebuah hosting web. Aplikasi Augmented Reality Endek Bali dirancang memiliki output berupa video corak kain endek Bali keseluruhan dimana penyampaian informasinya diperjelas dengan penambahan narasi berupa suara dan running text sesuai narasi informasi. Kelebihan dari pengembangan Aplikasi Augmented Reality Endek Bali adalah pengurangan penyimpanan data input maupun output aplikasi pada memori smartphone sekaligus mempermudah proses update data input maupun output pada Aplikasi Augmented Reality Endek Bali.

\subsection{Kain Endek Bali}

Kain endek adalah kain tenun ikat yang cara pembuatannya dengan memberikan corak pada benang pakan sebelum ditenun [1]. Kain endek Bali memiliki bermacam-macam corak diantaranya corak alam seperti corak bunga dan binatang, corak patra bali, corak modifikasi dan lainnya. Kain endek bercorak modifikasi adalah kain endek yang memiliki corak hasil modifikasi pengrajin kain endek Bali. Proses pembuatan corak kain endek Bali yang dilakukan sesuai dengan cita rasa seni dari pembuat corak kain endek Bali. Kain endek Bali termasuk dalam salah satu budaya Bali, bisa dikatakan sebagai warisan budaya Bali.

\subsection{Augmented Reality}

Augmented Reality (AR) adalah suatu teknologi yang menggabungkan benda maya 2 dimensi dan ataupun 3 dimensi ke dalam sebuah lingkungan nyata 3 dimensi lalu memproyeksikan benda-benda maya dalam waktu nyata. Augmented Reality hanya menambahkan atau melengkapi kenyataan, tidak seperti realitas maya yang sepenuhnya menggantikan kenyataan. Augmented reality menggabungkan benda-benda nyata dan virtual objects yang ada. Virtual objects dapat berupa teks, animasi, model 3D atau video yang digabungkan dengan lingkungan sebenarnya sehingga pengguna merasakan virtual objects berada dilingkungannya [3].

\subsection{Vuforia SDK}

Vuforia SDK adalah Software Development Kit berbasis AR yang menggunakan layar perangkat mobile sebagai "lensa ajaib" atau kaca untuk melihat kedalam dunia Augmented dimana dunia nyata dan virtual muncul berdampingan. Vuforia SDK membuat preview kamera secara langsung pada layar smartphone untuk mewakili pandangan dari dunia fisik. Objek 3D nampak secara langsung dilayar smartphone, sehingga terlihat objek 3D berada didalam dunia nyata, vuforia SDK terdiri dari 2 komponen utama yaitu library QCAR dan target management system [4].

\subsection{Unity 3D}

Unity 3D adalah sebuah game engine yang berbasis cross-platform. Unity 3D dapat digunakan untuk membuat sebuah game yang bisa digunakan pada perangkat komputer, 
Android, iPhone, Playstation, dan X-Box. Unity 3D adalah sebuah tool yang terintegrasi untuk membuat game, arsitektur bangunan dan simulasi. Unity 3D bisa digunakan untuk $P C$ games dan online games. Penggunaan dalam online game diperlukan sebuah plugin, yaitu unity web player seperti flash player pada browser [5].

\section{Hasil dan Pembahasan}

Hasil dan pembahasan berisikan tentang pembahasan dari Aplikasi AR Endek Bali yang telah dirancang, pengujian aplikasi dan analisis hasil didapat setelah melakukan pengujian terhadap Aplikasi AR Endek Bali.

\subsection{User Interface Aplikasi Augmented Reality Endek Bali}

Aplikasi AR Endek Bali memiliki 6 scene untuk user meliputi Scene Splashscreen, Scene Main Menu, Scene Scanner, Scene Videoplay, Scene Tutorial dan Scene About. Berikut adalah hasil printscreen dari masing-masing scene pada Aplikasi AR Endek Bali.

\subsubsection{Scene Splashscreen}

Scene Splashscreen merupakan tampilan awal saat user menjalankan aplikasi sebelum masuk ke Scene Main Menu. Gambar 3 menunjukkan tampilan dari Scene Splashscreen

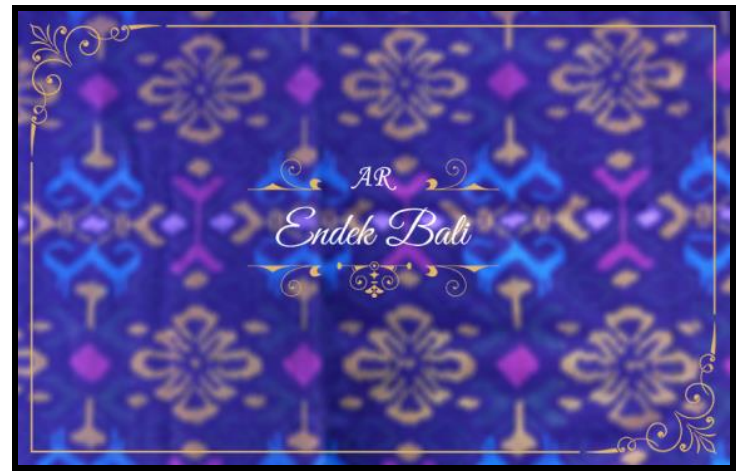

Gambar 3. Scene Splashscreen pada Aplikasi AR Endek Bali

\subsubsection{Scene Main Menu}

Scene Main Menu merupakan tampilan setelah Scene Splashscreen muncul pada Aplikasi AR Endek Bali. Scene Main Menu berfungsi untuk mempermudah user menjalankan beberapa fungsi aplikasi saat user ingin menuju ke aktivitas tertentu pada Aplikasi AR Endek Bali. Gambar 4 menunjukkan tampilan Scene Main Menu pada Aplikasi AR Endek Bali.

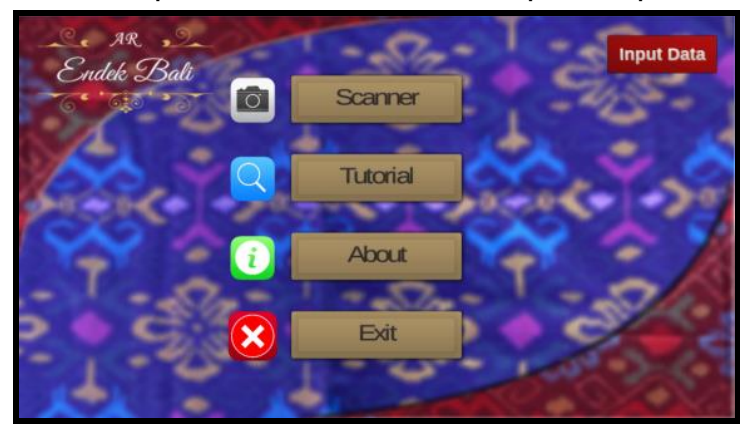

Gambar 4. Scene Main Menu pada Aplikasi AR Endek Bali

\subsubsection{Scene Scanner}

Scene Scanner merupakan scene utama dari Aplikasi AR Endek Bali. Proses scanning diakses melalui tombol scanner pada Scene Main Menu untuk menuju Scene Scanner. Scene Scanner memiliki tombol back dan 3 buah text field. Tombol back pada Scene Scanner berupa icon tanda panah berwarna biru yang berfungsi untuk kembali ke Scene Main Menu. Fungsi dari masing-masing 3 text field pada Scene Scanner diantaranya text field pertama berwarna putih paling kiri dekat tombol back adalah sebagai indikator menampilkan keterangan koneksi internet saat proses scanning pada aplikasi, text field kedua berwarna putih 
bagian tengah sebagai indikator menampilkan keterangan tidak adanya input-an link video, text field ketiga berwarna coklat adalah keterangan dari metadata marker yang terdeteksi. Gambar 5 menunjukkan tampilan Scene Scanner pada Aplikasi AR Endek Bali.

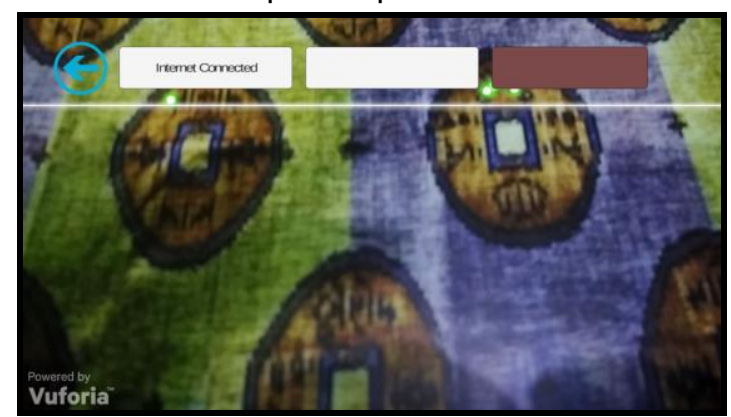

Gambar 5. Scene Scanner pada Aplikasi AR Endek Bali

\subsubsection{Scene VideoPlay}

Scene VideoPlay adalah scene khusus yang dibuat pada Unity 3D untuk menampilkan video narasi dengan running text yang berisi informasi corak kain endek Bali sesuai dengan marker yang terdeteksi. Scene VideoPlay muncul ketika marker yang di-scan terdeteksi dan dikenali kemudian video narasi dengan running text yang berisi informasi dari corak kain endek Bali yang terdeteksi ditampilkan pada layar smartphone. Gambar 6 menunjukkan video yang berhasil dimainkan saat marker berhasil dideteksi.

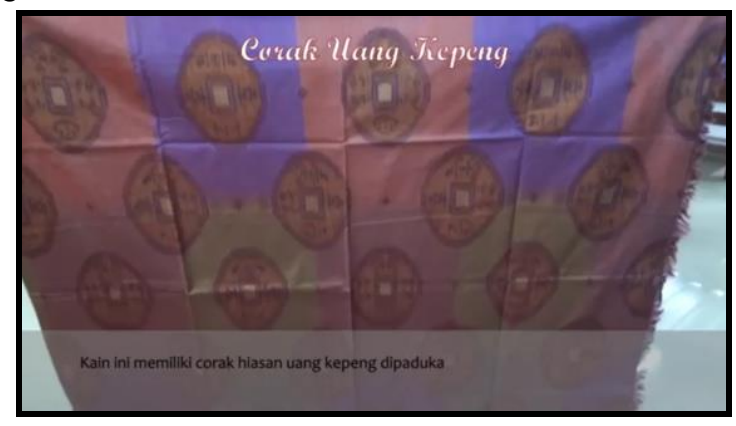

Gambar 6. Scene VideoPlay pada Aplikasi AR Endek Bali

\subsubsection{Scene Tutorial}

Scene Tutorial adalah scene yang ditampilkan ketika user memilih button tutorial pada Scene Main Menu Aplikasi AR Endek Bali. Scene Tutorial menampilkan penjelasan dari aplikasi dan deskripsi langkah penggunaan Aplikasi AR Endek Bali. Gambar 7 menunjukkan Scene Tutorial Aplikasi AR Endek Bali.

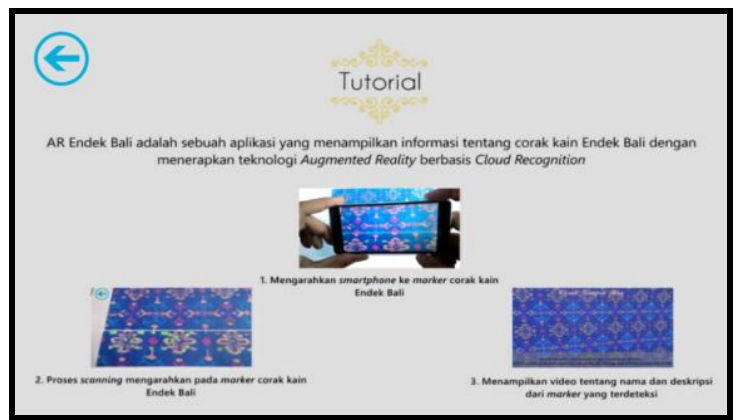

Gambar 7. Scene Tutorial pada Aplikasi AR Endek Bali

\subsubsection{Scene About}

Scene About adalah scene yang ditampilkan ketika user memilih button about pada Scene Main Menu Aplikasi AR Endek Bali. Scene About menampilkan identitas dari pembuat aplikasi dan logo perangkat lunak pendukung dalam pembuatan Aplikasi AR Endek Bali. Gambar 8 menunjukkan Scene About Aplikasi AR Endek Bali. 


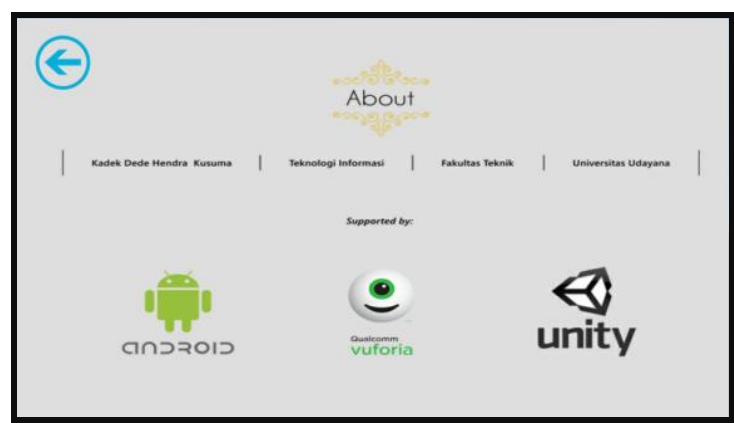

Gambar 8. Scene About pada Aplikasi AR Endek Bali

\subsection{Analisis Hasil}

Pengujian untuk analisa Aplikasi AR Endek Bali menggunakan metode survey untuk pengambilan data dan menggunakan kuesioner sebagai media pengumpulan data. Kuesioner diberikan kepada responden secara acak yang telah menggunakan Aplikasi AR Endek Bali dengan rentang umur 17 sampai 55 tahun.

\subsubsection{Kriteria Variabel}

Kriteria variabel adalah tanggapan responden setelah menggunakan Aplikasi AR Endek Bali. Beberapa variabel yang diamati dalam pengujian Aplikasi AR Endek Bali, antara lain aspek content dan aspek pengalaman pengguna.

1. Aspek Content

Penilaian yang mencakup aspek content dilakukan dengan memberikan penilaian dari 20 responden mengenai bentuk penyajian Informasi Corak Kain Endek Bali pada Aplikasi AR Endek Bali. Tabel 2 merupakan penilaian pada aspek content.

Tabel 2. Total Jumlah Penilaian Responden pada Aspek Content

\begin{tabular}{ccc}
\hline Pernyataan & Jumlah Responden & Persentase \\
\hline Ya & 14 & $70 \%$ \\
Tidak & 6 & $30 \%$ \\
Total & 20 & $100 \%$ \\
\hline
\end{tabular}

Pernyataan "Ya" pada Tabel 2 menunjukkan bentuk penyajian informasi tergolong menarik sedangkan pernyataan "Tidak" menunjukkan bentuk penyajian informasi tergolong tidak menarik. Penilaian responden terhadap aspek content yang didapat tergolong menarik dengan persentase jawaban "Ya" sebesar $70 \%$ dan sisa responden menyatakan penilaian terhadap aspek content tergolong tidak menarik dengan persentase jawaban "Tidak" sebesar $30 \%$.

2. Aspek Pengalaman Pengguna

Penilaian yang mencakup aspek pengalaman pengguna dilakukan dengan memberikan penilaian dari 20 responden mengenai manfaat yang didapat setelah responden menggunakan Aplikasi AR Endek Bali. Tabel 3 merupakan penilaian pada aspek pengalaman pengguna.

Tabel 3. Total Jumlah Penilaian Responden pada Aspek Pengalaman Pengguna

\begin{tabular}{ccc}
\hline Pernyataan & Jumlah Responden & Persentase \\
\hline Ya & 18 & $90 \%$ \\
Tidak & 2 & $10 \%$ \\
Total & 20 & $100 \%$ \\
\hline
\end{tabular}

Pernyataan "Ya" pada Tabel 3 menunjukkan Aplikasi AR Endek Bali tergolong bermanfaat dalam hal membantu memberikan Informasi Corak Kain Endek Bali sedangkan pernyataan "Tidak" menunjukkan Aplikasi AR Endek Bali tergolong tidak bermanfaat dalam hal membantu memberikan Informasi Corak Kain Endek Bali. Penilaian responden terhadap aspek pengalaman pengguna yang didapat tergolong bermanfaat dengan persentase jawaban "Ya" 
sebesar $90 \%$ dan sisa responden menyatakan penilaian terhadap aspek pengalaman pengguna tergolong tidak bermanfaat dengan persentase jawaban "Tidak" sebesar $10 \%$.

\section{Kesimpulan}

Aplikasi Augmented Reality Informasi Corak Kain Endek Bali pada Platform Android mampu menampilkan output video narasi dan running text Informasi Corak Kain Endek Bali yang tersimpan dalam sebuah web hosting. Proses awal dimulai dengan melakukan proses scanning dan pencocokan input marker Corak Kain Endek Bali yang telah terdaftar dalam cloud database marker sehingga dapat menampilkan output yang sesuai dengan marker yang cocok. Input dan output Aplikasi Augmented Reality Endek Bali tidak disimpan dalam device sehingga proses pendeteksian hingga menampilkan output membutuhkan koneksi internet. Kelebihan Aplikasi Augmented Reality Endek Bali diantaranya simpanan data input dan output Aplikasi Augmented Reality Endek Bali berkurang sehingga mengurangi penyimpanan data aplikasi pada memori smartphone. Penerapan cloud database untuk data marker sebagai input serta web hosting untuk content Aplikasi Augmented Reality Endek Bali mempermudah proses update data target marker dan content pada Aplikasi Augmented Reality Endek Bali. Aplikasi Augmented Reality Endek Bali tergolong menarik dalam bentuk penyajian Informasi Corak Kain Endek Bali berdasarkan kuesioner dengan hasil persentase sebesar $70 \%$ pada aspek content. Aplikasi Augmented Reality Endek Bali tergolong bermanfaat dalam memberikan Informasi Corak Kain Endek Bali berdasarkan kuesioner dengan hasil persentase sebesar $90 \%$ pada aspek pengalaman pengguna Aplikasi Augmented Reality Endek Bali. Hasil kuesioner yang diperoleh membuktikan Aplikasi Augmented Reality Endek Bali dapat membantu mempermudah akses informasi tentang Corak Kain Endek Bali kepada masyarakat sehingga diharapkan dapat mendukung eksistensi corak Kain Endek Bali seiring perkembangan zaman.

\section{Daftar Pustaka}

[1] D. H. Putri, I. S. Wayan, and I. G. S. Mananda, "Analisis Strategi Pemasaran Kain Endek Bali Sebagai Industri Pariwisata Kreatif (Studi Kasus Denpasar)," IPTA, vol. 3, no. 2, pp. 7-12, 2015.

[2] M. F. Rentor, "Rancang Bangun Perangkat Lunak Pengenalan Motif Batik Berbasis Augmented Reality," Universitas Atma Jaya Yogyakarta, 2013.

[3] I. D. G. W. Dhiyatmika, I. K. G. D. Putra, and N. M. I. M. Mandenni, "Aplikasi Augmented Reality Magic Book Pengenalan Binatang untuk Siswa TK," Lontar Komputer, vol. 6, no. 2, pp. 589-596, 2015.

[4] A. Astridefi, G. M. A. Sasmita, and N. K. D. Rusjayanthi, "Aplikasi Pengenalan Profil Negara di ASEAN Berbasis Augmented Reality," Merpati, vol. 4, no. 1, pp. 155-162, 2016.

[5] I. G. A. Nugraha, I. K. G. Darma Putra, and I. M. Sukarsa, "Rancang Bangun Aplikasi Augmented Reality Museum Bali Berbasis Android Studi Kasus Gedung Karangasem dan Gedung Tabanan," Lontar Komputer, vol. 7, no. 2, pp. 768-778, 2016.

[6] A. F. Waruwu, I. P. A. Bayupati, and I. K. G. Darma Putra, "Augmented Reality Mobile Application of Balinese Hindu Temples: DewataAR," Ijcnis, no. January, pp. 59-66, 2015.

[7] A. A. K. O. Oka Sudana, I. W. M. Sujana, and N. K. D. Rusjayanthi, "Arbantenotonan: A learning Media Base on Augmented Reality Traditional Balinese Birthday Ceremony Equipment," Journal of Theoretical and Applied Information Technology, vol. 95, no. 7, pp. 1362-1369, 2017.

[8] D. A. S. Dewi, I. K. G. D. Putra, and I. P. A. Bayupati, "Aplikasi Augmented Reality Jurusan Teknologi Informasi Universitas Udayana ( AR-TI )," Merpati, vol. 5, pp. 9-16, 2017.

[9] N. P. Y. S. Putri, I. G. M. Darmawiguna, and G. S. Santyadiputra, "Pengembangan Aplikasi Buku Menu Rumah Makan Bebek Tepi Sawah Berbasis Augmented Reality," KARMAPATI, vol. 4, no. 4, 2015.

[10] C. A. S. Lahallo, A. A. K. A. C. Wiranatha, and G. M. A. Sasmita, "Media Pembelajaran Molymod Senyawa Hidrokarbon Teknologi Augmented Reality Berbasis Android," Merpati, vol. 4, no. 1, pp. 123-134, 2016. 